Egyptian Journal of Aquatic Biology \& Fisheries

Zoology Department, Faculty of Science,

Ain Shams University, Cairo, Egypt.

ISSN 1110 - 6131 Vol. 21(2): 33-46 (2017)

www.ejabf.js.iknito.com

\title{
Length-Weight Relationship and Condition Factor of Some Fishes from the River Nile in Egypt with Special Reference to Four Tilapia Species
}

\author{
Shalloof, K. A. Sh. ${ }^{1,2^{*}}$ and El- Far, A. M. ${ }^{2}$ \\ 1- Biology Department, Faculty of Science and Home Domestics, Bisha University, Saudi Arabia. \\ 2- Fisheries Division, National Institute of Oceanography and Fisheries, Egypt. \\ *Correspondence to Kariman Shalloof , E-mail: dr_kariman88@yahoo.com
}

\begin{tabular}{l} 
ARTICLE INFO \\
Article History: \\
Received: Mar. 2017 \\
Accepted: May 2017 \\
Available online: May 2017 \\
\hline
\end{tabular}

Keywords:

Length-weight relationship Condition factor

River Nile

Cichlids

\section{ABSTRACT}

This study has been carried out along the River Nile (river main stream, Rosetta and Damietta branches) in Egypt. Fish Samples of 21 species belonging to 11 families were collected mainly from the catch of three fishing gears and methods, Trammel net, Traps, and Longlines. Total length $(\mathrm{cm})$ and body weight $(\mathrm{g})$ were measured and data were applied to the equation of $\mathrm{W}=\mathrm{a} \mathrm{L}^{\mathbf{b}}$, for the length-weight relationship and $\mathrm{K}=100 \times \mathrm{W} / \mathrm{L}^{3}$ for condition factor. Four cichlid species, namely: Oreochromis niloticus, Oreochromis aureus, Tilapia zillii and Sarotherodon galilaeus were investigated in details. T. zillii exhibits isometric growth in both main stream and Damietta branch, where, relative growth coefficient (b) $=3.0266$ and 2.9698, respectively. $S$. galilaeus follows the same pattern in Rosetta branch ( $b=3.0154)$. Generally, allometric growth noticed for the four studied species in the three branches of the River Nile. The value of (K) of different cichlid species was fluctuated during different seasons in the three studied areas of the River Nile. The value of condition factor of the four studied species inversely related to the size of fish. In general, variation in the most studied biological characters of cichlid species in the three studied areas of River Nile was noticed. Allometric growth for the four studied species in the three branches of the river indicating increase of pollution. The present study recommends that these selected sectors need proper management.

\section{INTRODUCTION}

The Nile considered as one of the major sources of fish production in Egypt, since it constitutes $23.3 \%$ of the total fish production of natural sources in Egypt (GAFRD, 2015).The Nile extends for about $950 \mathrm{~km}$ from Aswan High Dam to Cairo. Then, the Nile is divided into two branches, the Rosetta and the Damietta branch each branch is about $200 \mathrm{~km}$ in length and finally reaches the Mediterranean Sea. It runs through Egypt, creating a fertile green valley across the desert. The River Nile 
discharges its water into the Mediterranean Sea through two branches (Damietta and Rosetta branches) in addition to a network of agricultural drains that discharges mostly indirectly, through the northern lakes of Al- Manzalah, Borollous, Edku and Mariut(Raslan and Abdelbary, 2001).

The relation between body weight and length is a simple but essential in a fishery management (Chien- Chung, 1999). This relation represents one of the most studied biological characters of fish biology. It is known that weight of a fish increases as a function of its length. Length-weight relationship is an essential biological parameter needed to appreciate the suitability of the environment for any fish (Moussa, 2003). Length-weight relationships for fish used extensively to provide information on the condition of fish, their isometric or allometric growth, in the analysis of ontogenic changes, to compare life histories of fish species between regions as well as other aspects of fish population dynamics. In fisheries biology, length-weight relationships are useful for the conversion of growth-in-length equations to growth-in-weight, for use in stock assessment models and to estimate stock biomass from limited sample sizes (Binohlan and Pauly, 1998; Koutrakis and Tsikliras, 2003; Ecoutin et al., 2005)

In addition, these relationships contribute to the comparison of life history and morphological aspects of populations between different regions of the same country (Sedaghat and Hoseini, 2012). According to Lawson (2011), the investigations on the length-weight relationship studies are important in managing and conserving fish species in one habitat. Meanwhile, the condition factor $(\mathrm{K})$ of fish is actually considering the general wellbeing and health of fish in relation to its environment (Reynold, 1968). Gallardo-Cabello et al. (2007), mentioned that the $\mathrm{K}$ of fish diminished when the food availability in one area decreased. Condition factor is also a useful index for the monitoring of feeding intensity, age, and growth rates in fish (Oni et al., 1983). It strongly influenced by both biotic and abiotic environmental conditions and can be used as an index to assess the status of the aquatic ecosystem in which fish live (Anene, 2005).

Since Tilapia species constitutes the major bulk of the River Nile- more than $33.0 \%$ of the total catch (GAFARD, 2015), the objective of the present study was to provide information on the length-weight relationship and condition factor of the most dominant cichlid species, in its three branches to attempt managing of these species.

\section{MATRIALS AND METHODS}

The area of investigation divided into three areas, namely: the main stream that is extended from Aswan to Shoubra El- Kheima for about $970 \mathrm{Km}$; Rosetta branch that is extended from Shoubra -El-Kheima to Rashid for about $200 \mathrm{Km}$ and Damietta branch that is extended from Shoubra El- Kheima to Damietta for about $200 \mathrm{Km}$ (Fig.1).

Fish samples were collected using different fishing gears and methods as trammel net (Dabba, El-Mehhaier or Shebak El-Dak), basket traps (Gwabi) and hooks $\&$ line (Sennar) during the period from April 2008 to May 2009. Fish were sorted to species level according to Bishai and Khalil (1997) and FishBase (2016); then total length was measured to the nearest $0.1 \mathrm{~cm}$ and weighed to the nearest $0.1 \mathrm{~g}$. The relation between length and weight and condition factor $(\mathbf{K})$ was calculated according to Le Cren (1936) and Ricker (1975) from the following equations:

$$
W=a L^{b} \text { and } K=100 \times W / L^{3}
$$


Where $\mathrm{L}$ is the total length in $\mathrm{cm}$; $\mathrm{W}$ is the total weight in $\mathrm{g}$ and (a) and (b) are constants which estimated from the least square method. Correlation coefficient $(\boldsymbol{r})$ and standard deviation of the obtained biological data was computed using SPSS program, (Ver., 16).

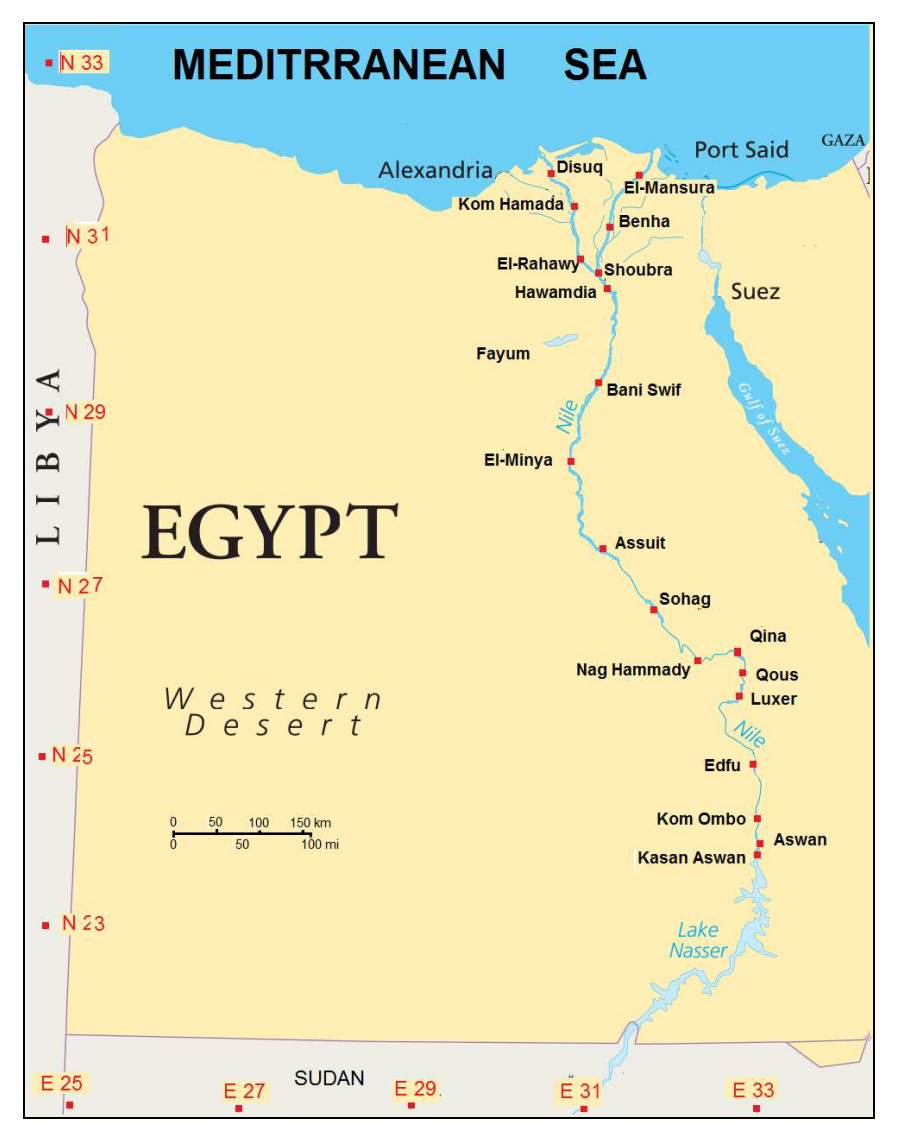

Fig. (1) The River Nile in Egypt, showing the samples collection sites

\section{RESULTS}

About 21 species along the River have been detected in the present study. Catch composition in the main stream during the period of investigation was represented by four cichlid species namely, Oreochromis niloticus, Oreochromis aureus, Tilapia (Coptodon) zillii and Sarotherodon galilaeus. In addition, Lates niloticus, Clarias gariepinus, Synodontis clarias, Shelba (Eutropius) niloticus, Mormyrus kannume, Ctenopharyngodon idella (C\&V), Barbus bynni, Chrysichthys auratus, Bagarus bayad, Haplochromis bloyeti, Hydrocynus forskalii and Atherina boyeri were represented in the catch. In Rosetta branch, species distribution was represented by $O$. niloticus, O. aureus, T. zillii, S. galilaeus, L. niloticus, C. gariepinus, B. bynni, B. bayad, H. bloyeti, Hemichromis bimaculatus, Brycinus nurse, Labeo niloticus, Labeo horie and Hypophthaimichthys molitrix. The most abundant species in Damietta branch was $T$. zillii, followed by $O$. niloticus and $S$. galilaeus.

Length range, mean length, weight range and its mean of fish of the River Nile are given in table (1). Regarding to the size composition, the length ranges of $O$. niloticus were 9.6- 35.4; 8.3- 28.6 and $10.8-26.1 \mathrm{~cm}$ with an averages $16.5,15.7$ and $16.4 \mathrm{~cm}$ corresponding to weight ranges from 14.3- 1140.0; 16.0- 537.0 and 15.7$247.5 \mathrm{~g}$ with an average weights $99.9 ; 91.6$ and $92.4 \mathrm{~g}$ in the main stream, Rosetta and Damietta branches, respectively, whereas, the average lengths of $O$. aureus were 
$13.8,13.5$ and $17.3 \mathrm{~cm}$ corresponding to an average weights of $48.0 ; 47.6$ and $81.7 \mathrm{~g}$ in the former three branches, respectively as shown in tables (2 and 3). The best average lengths and weights of $T$. zillii and S. galilaeus were observed in the main stream, since it is valued as 15.5 and $16.9 \mathrm{~cm} \& 79.7$ and $106.8 \mathrm{~g}$ for both two species, respectively.

Table (1): Fish Length, weight, condition factor and length-weight relationship parameters of fish of

\begin{tabular}{|c|c|c|c|c|c|c|c|c|c|c|c|}
\hline \multirow{2}{*}{$\underline{\text { Species }}$} & \multirow{2}{*}{ No. } & \multicolumn{3}{|c|}{ Total length $(\mathrm{cm})$} & \multicolumn{3}{|c|}{ Total weight (g) } & \multirow{2}{*}{ K-Factor } & \multicolumn{3}{|c|}{ L-wt relationship $\left(W=a L^{b}\right)$} \\
\hline & & Min & Max. & Avr. & Min & Max. & Avr. & & $\mathbf{a}$ & b & $\mathbf{R}^{2}$ \\
\hline Atherina boyeri & 3 & 8.5 & 22.0 & 13.5 & 3.0 & 76.1 & 28.4 & 0.601 & - & - & - \\
\hline Bagrus bajad & 8 & 16.8 & 51.0 & 33.4 & 46.9 & 1800.0 & 579.6 & 0.954 & 0.004 & 3.239 & 0.9596 \\
\hline Barbus bynni & 8 & 8.4 & 36.2 & 25.1 & 8.0 & 640.0 & 234.3 & 1.095 & 0.014 & 2.907 & 0.9737 \\
\hline Brycinus nurse & 5 & 11.8 & 28.4 & 17.7 & 15.9 & 128.0 & 59.0 & 1.011 & - & - & - \\
\hline Chrysichthys auratus & 11 & 13.6 & 23.8 & 16.6 & 26.3 & 163.8 & 62.3 & 1.184 & 0.013 & 2.980 & 0.9637 \\
\hline Claries gariepinus & 8 & 41.0 & 54.5 & 46.8 & 495.0 & 1250.0 & 748.8 & 0.710 & 0.007 & 3.007 & 0.9717 \\
\hline Ctenopharyngodon idella & 26 & 9.0 & 41.1 & 24.9 & 8.9 & 880.0 & 303.3 & 1.712 & 0.039 & 2.719 & 0.9133 \\
\hline Eutroplus(Shilbe) niloticus & 6 & 18.4 & 27.2 & 22.9 & 15.7 & 132.9 & 84.4 & 0.629 & - & - & - \\
\hline Haplochromis bloyeti & 1 & 9.7 & 9.7 & 9.7 & 20.0 & 20.0 & 20.0 & 2.191 & - & - & - \\
\hline Hemichromis bimaculatus & 5 & 9.0 & 13.1 & 10.8 & 11.0 & 41.8 & 25.2 & 1.843 & - & - & - \\
\hline Hydrocynus forskalii & 3 & 27.4 & 31.1 & 29.4 & 104.0 & 139.1 & 126.7 & 0.834 & - & - & - \\
\hline Hypophthaimichthys molitrix & 2 & 23.4 & 24.1 & 23.8 & 137.2 & 155.0 & 146.1 & 1.089 & - & - & - \\
\hline Labeo forskallii & 5 & 13.5 & 27.0 & 23.1 & 24.0 & 165.0 & 109.4 & 0.833 & - & - & - \\
\hline Lates niloticus & 45 & 18.4 & 61.1 & 32.9 & 74.9 & 1800 & 408.3 & 1.043 & 0.102 & 2.327 & 0.9077 \\
\hline Mormyrus kannume & 2 & 33.3 & 55.0 & 44.2 & 215.1 & 504.0 & 359.6 & 0.443 & - & - & - \\
\hline Mormyrus(pollimyrus) isidori & 1 & 11.0 & 11.0 & 11.0 & 10.7 & 10.7 & 10.7 & 0.804 & - & - & - \\
\hline Oreochromis aureus & 74 & 11.0 & 20.7 & 14.6 & 22.0 & 207.8 & 57.0 & 1.759 & 0.081 & 2.420 & 0.8296 \\
\hline Oreochromis niloticus & 801 & 8.3 & 35.4 & 16.2 & 14.3 & 875.0 & 95.8 & 1.919 & 0.018 & 3.017 & 0.9114 \\
\hline Sarotherdon galilaeus & 217 & 9.0 & 26.2 & 15.8 & 14.0 & 310.0 & 90.5 & 2.006 & 0.024 & 2.926 & 0.9294 \\
\hline Synodontis schall & 3 & 24.2 & 35.1 & 30.9 & 180.0 & 650.0 & 463.3 & 1.437 & - & - & - \\
\hline Tilapia zillii & 296 & 7.1 & 24.3 & 14.3 & 7.0 & 265.1 & 65.00 & 1.917 & 0.019 & 2.997 & 0.9453 \\
\hline
\end{tabular}

Table (2): Average lengths and their range $(\mathrm{cm})$ of different cichlid species caught from different branches of River Nile during the period of investigation.

\begin{tabular}{lcccccc}
\hline \multirow{2}{*}{ Species } & \multicolumn{2}{c}{ Main stream } & \multicolumn{2}{c}{ Rosetta branch } & \multicolumn{2}{c}{ Damietta branch } \\
\cline { 2 - 7 } & Av. L. $(\mathrm{cm})$ & $\begin{array}{c}\text { Range } \\
\text { L. }(\mathrm{cm})\end{array}$ & Av. L. $(\mathrm{cm})$ & $\begin{array}{c}\text { Range } \\
\text { L. }(\mathrm{cm})\end{array}$ & Av. L. (cm) & $\begin{array}{c}\text { Range } \\
\text { L. }(\mathrm{cm})\end{array}$ \\
\hline O. niloticus & 16.5 & $9.6-37.4$ & 15.7 & $8.3-28.6$ & 16.4 & $10.8-26.1$ \\
O. aureus & 13.8 & $11.2-20.7$ & 13.5 & $11.6-16.0$ & 17.3 & $11.0-20.2$ \\
T. zillii & 15.5 & $8.0-24.3$ & 12.0 & $7.1-21.2$ & 11.5 & $7.7-16.4$ \\
S.galilaeus & 16.9 & $10.5-26.2$ & 13.7 & $9.0-21.7$ & 16.0 & $10.5-23.0$ \\
& & & & & & \\
\hline
\end{tabular}


Table (3): Average weights and their range ( $\mathrm{g}$ ) of different cichlid species caught from different branches of River Nile during the period of investigation.

\begin{tabular}{ccccccc}
\hline \multirow{2}{*}{ Species } & \multicolumn{2}{c}{ Main stream } & \multicolumn{2}{c}{ Rosetta branch } & \multicolumn{2}{c}{ Damietta branch } \\
\cline { 2 - 7 } & Av. Wt. (g) & $\begin{array}{c}\text { Range } \\
\text { Wt.(g) }\end{array}$ & Av. Wt. (g) & Range & Av. Wt. (g) & Range \\
& & & Wt.(g) & & Wt.(g) \\
\hline O. niloticus & 99.9 & $14.3-1140.0$ & 91.6 & $16.0-537.0$ & 92.4 & $15.7-247.5$ \\
O. aureus & 48.0 & $25.5-207.0$ & 47.6 & $41.2-77.0$ & 81.7 & $22.0-130.0$ \\
T. zillii & 79.7 & $10.0-264.2$ & 37.2 & $13.1-217.3$ & 28.4 & $8.2-80.7$ \\
S. galilaeus & 106.8 & $26.1-310.0$ & 65.2 & $15.3-215.0$ & 85.9 & $15.9-260.0$ \\
& & & & & & \\
\hline
\end{tabular}

A wide range of the mean lengths for $O$. niloticus, during the period of investigation were recorded and ranged from $8.3-35.4 \mathrm{~cm}$, with the mean lengths of $16.0 \mathrm{~cm}$. Weights of $O$. niloticus ranged from $16-1140 \mathrm{~g}$, with meaning of $97.09 \mathrm{~g}$.

The result indicated that, high correlations between length and weight of the studied cichlid species were existed, where $r=0.9589,0.9152,0.9687$ and 0.9612 ; $0.9741,0.8528,0.9465$ and $0.9738 \& 0.9523,0.9388,0.9522$ and 0.9442 for $O$. niloticus, O. aureus, T. zillii and S. galilaeus, in the main stream, Rosetta and Damietta branches, respectively. The highest value of the factor (b) for O. niloticus, O. aureus and T. zillii was noticed in the main stream (3.1699, 3.226 and 3.0266), whereas the lowest was recorded in Rosetta branch $(2.7258,1.6473$ and 2.5992 for the previous three species, respectively). In contrast, S. galilaeus has the highest value of (b) in Damietta and Rosetta branches more than main stream (Table 4).

Table (4): Main parameters of dependence of length upon weight of different cichlid species in different localities of River Nile, Egypt during the period of investigation.

\begin{tabular}{|c||c|c|c||c|c||c||c|c|c|}
\hline \multirow{2}{*}{\multicolumn{1}{|c||}{ Species }} & \multicolumn{3}{c||}{ Main stream } & \multicolumn{3}{c||}{ Rosetta branch } & \multicolumn{3}{c|}{ Damietta branch } \\
\cline { 2 - 10 } & $\mathrm{a}$ & $\mathrm{b}$ & $\mathrm{r}$ & $\mathrm{a}$ & $\mathrm{b}$ & $\mathrm{r}$ & $\mathrm{a}$ & $\mathrm{b}$ & $\mathrm{R}$ \\
\hline \hline $\begin{array}{c}\text { O. } \\
\text { niloticus }\end{array}$ & 0.0114 & 3.1699 & 0.9589 & 0.0440 & 2.7258 & 0.9741 & 0.0155 & 3.0633 & 0.9523 \\
\hline O. aureus & 0.0091 & 3.2260 & 0.9152 & 0.6484 & 1.6473 & 0.8528 & 0.0947 & 2.3593 & 0.9388 \\
\hline T. zillii & 0.0178 & 3.0266 & 0.9687 & 0.0524 & 2.5992 & 0.9465 & 0.0179 & 2.9698 & 0.9522 \\
\hline S.galilaeus & 0.0248 & 2.9174 & 0.9612 & 0.0203 & 3.0154 & 0.9738 & 0.0138 & 3.097 & 0.9442 \\
\hline
\end{tabular}

T. zillii exhibits isometric growth in both Main stream and Damietta branch (3.0266 and 2.9698, respectively), whereas, S. galilaeus follow the same pattern in Rosetta branch (3.0154). Generally, allometric growth noticed for the four studied species in the main stream, Rosetta and Damietta branches (Fig. 2). It was clear that there was a significant deference between all locations for all species except between Rosetta and Dameitta branches for Tilapia zillii (Table 5). 


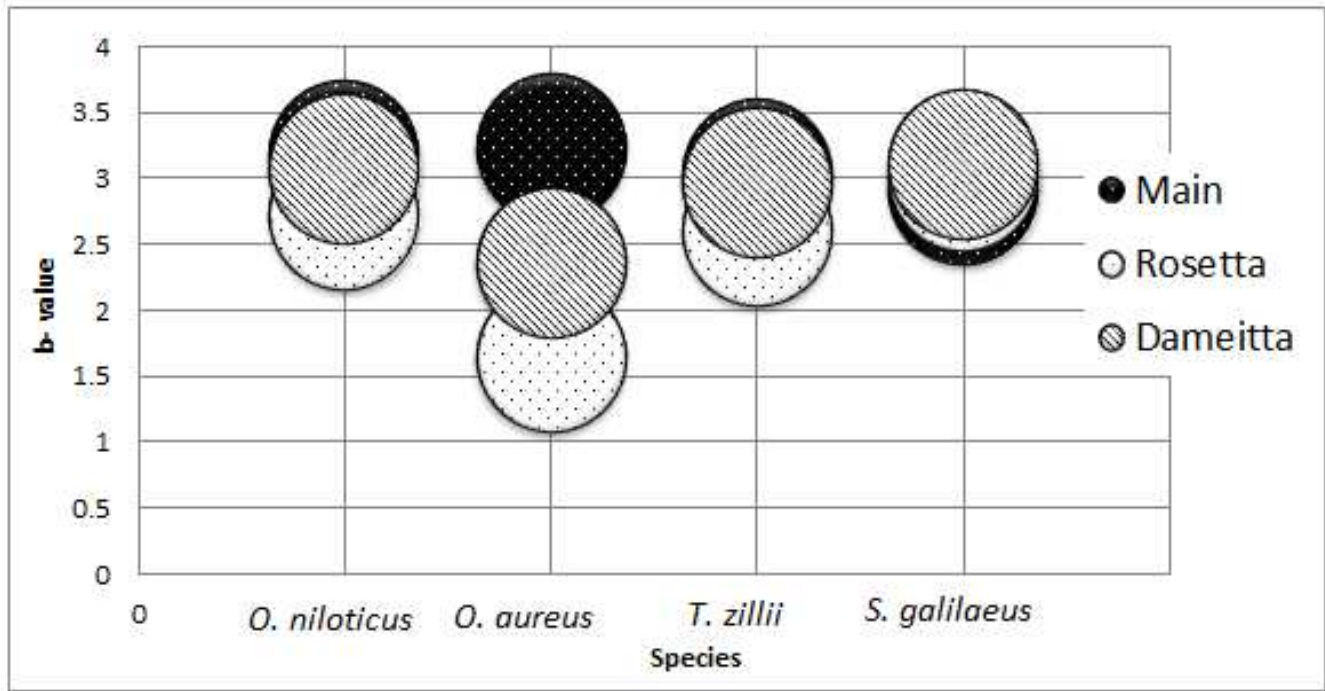

Fig (2): b- values of length-weight relationship (W=a $\mathbf{L}^{\mathbf{b}}$ ) for Cichlids species from different location of River Nile, during the period of investigation.

Table (5): $t$-test of length-weight relationship of Cichlid species from different locations in Nile River (M, main stream; R, Rosetta Branch and D, Damietta Branch) during the period of investigation.

\begin{tabular}{|c||c||c|c|c|}
\hline \hline Species & $\begin{array}{c}\text { Compared } \\
\text { location }\end{array}$ & $\begin{array}{c}\text { Standard } \\
\text { Error }\end{array}$ & $\begin{array}{c}\text { Standard } \\
\text { Deviation }\end{array}$ & $\begin{array}{c}\text { T-test value } \\
(\mathbf{P}=\mathbf{0 . 0 5})\end{array}$ \\
\hline \hline \multirow{2}{*}{ O. niloticus } & M-R & 11.102 & 57.690 & 0.005 \\
& M-D & 3.663 & 19.043 & 0.001 \\
& R-D & 7.443 & 38.674 & 0.010 \\
\hline \hline \multirow{2}{*}{ O. aureus } & M-R & 18.788 & 77.467 & 0.003 \\
& M-D & 12.230 & 50.423 & 0.004 \\
& R-D & 6.578 & 27.121 & 0.003 \\
\hline \hline T. zillii & M-R & 3.874 & 15.004 & 0.013 \\
& M-D & 6.285 & 10.010 & 0.000 \\
\hline \hline S. galilaeus & R-D & 1.343 & 5.201 & $0.546^{*}$ \\
& M-R & 3.200 & 13.195 & 0.000 \\
& M-D & 0.489 & 2.0145 & 0.000 \\
& R-D & 2.996 & 12.354 & 0.000 \\
\hline \hline
\end{tabular}

* No significant deference

The best mean condition factor $(\mathrm{K})$ of cichlid was recorded for $O$. niloticus and T. zillii in Rosetta branch (2.1 and 1.99, respectively). Highest condition also recorded for S. galilaeus in both Rosetta and main stream (2.14 and 2.00, respectively) as shown in table (6). Generally, four cichlid species in the three branches of the River Nile were in a good condition. Regarding to the seasonal variation in $\mathrm{K}$, it was found that, the best condition of $O$. niloticus was recorded in winter in both Rosetta and Damietta branches (2.4 and 2.16, respectively), whereas the lowest was recorded in spring in Damietta branch (1.47). The highest condition of $O$. aureus also recorded in Rosetta branch during winter season (2.34) followed by summer season in both main stream and Damietta branches (2.11 and 2.03, respectively). The lowest (K) of $O$. aureus was recorded in spring season in the main stream and Damietta branches (1.5 and 1.44, respectively). The elevation in condition of $(\mathrm{K})$ of $T$. zillii was recorded also in Rosetta and main stream during winter season (2.40 and 2.02, respectively). Decreasing in (K) of $T$. zillii was recorded in spring in Damietta (1.32). The highest condition of $S$. galilaeus was observed in winter and autumn seasons in Rosetta 
branch (2.24 and 2.31, respectively), and the lowest was recorded in spring (1.47). From the previous table, it concluded that, $\mathrm{K}$ value of different cichlid species was fluctuated during different seasons in the three studied areas of the River Nile.

Table (6): Mean condition factor $(\mathrm{K})( \pm \mathrm{SD})$ of different cichlid species during different seasons from different branches of River Nile during the period of investigation.

\begin{tabular}{|c|c|c|c|c|c|c|c|c|c|c|c|c|}
\hline \multirow[t]{2}{*}{ Species } & \multicolumn{3}{|c|}{ O.niloticus } & \multicolumn{3}{|c|}{ O.aureus } & \multicolumn{3}{|c|}{ T.zillii } & \multicolumn{3}{|c|}{ S.galilaeus } \\
\hline & $\mathrm{M}$ & $\mathrm{R}$ & $\mathrm{D}$ & $\mathrm{M}$ & $\mathrm{R}$ & $\mathrm{D}$ & $\mathrm{M}$ & $\mathrm{R}$ & $\mathrm{D}$ & $\mathrm{M}$ & $\mathrm{R}$ & $\mathrm{D}$ \\
\hline Spring & 1.59 & 1.88 & 1.47 & 1.51 & 1.84 & 1.44 & 1.86 & 1.87 & 1.32 & 1.86 & 2.04 & 1.47 \\
\hline$\pm \mathrm{SD}$ & 0.34 & 0.153 & 0.12 & 0.40 & 0.21 & 0.19 & 0.32 & 0.31 & 0.06 & 0.33 & 0.17 & 0.12 \\
\hline Summer & 1.90 & 2.00 & 1.83 & 2.11 & 1.89 & 2.03 & 1.80 & 1.72 & 1.59 & 2.14 & 1.86 & 1.99 \\
\hline$\pm \mathrm{SD}$ & 0.27 & 0.228 & 0.41 & 0.01 & 0.09 & 0.25 & 0.28 & 0.20 & 0.17 & 0.72 & 0.26 & 0.53 \\
\hline Autumn & 2.04 & 1.94 & 1.91 & - & 1.74 & 1.62 & 2.00 & 1.90 & 1.89 & 2.09 & 2.31 & 1.99 \\
\hline$\pm \mathrm{SD}$ & 0.21 & 0.212 & 0.19 & - & 0.25 & 0.04 & 0.14 & 0.13 & 0.28 & 0.19 & 0.65 & 0.26 \\
\hline Winter & 1.93 & 2.40 & 2.16 & 1.73 & 2.34 & - & 2.02 & 2.40 & 1.92 & 1.92 & 2.24 & 1.90 \\
\hline$\pm \mathrm{SD}$ & 0.41 & 0.268 & 0.33 & 0.13 & 0.26 & - & 0.22 & 0.51 & 0.02 & 0.18 & 0.27 & 0.12 \\
\hline Total & 1.86 & 2.10 & 1.88 & 1.67 & 1.96 & 1.56 & 1.93 & 1.99 & 1.69 & 2.00 & 2.14 & 1.84 \\
\hline
\end{tabular}

M: Main stream, R: Rosetta branch, D: Damietta branch, \pm SD: Standard deviation

Regarding to the variation in mean condition $(\mathrm{K})$ with size of different cichlid relation, the value of condition factor of $O$. niloticus $O$. aureus, $T$. zillii and $S$. galilaeus were inversely related to the size of fish (Fig. 3).
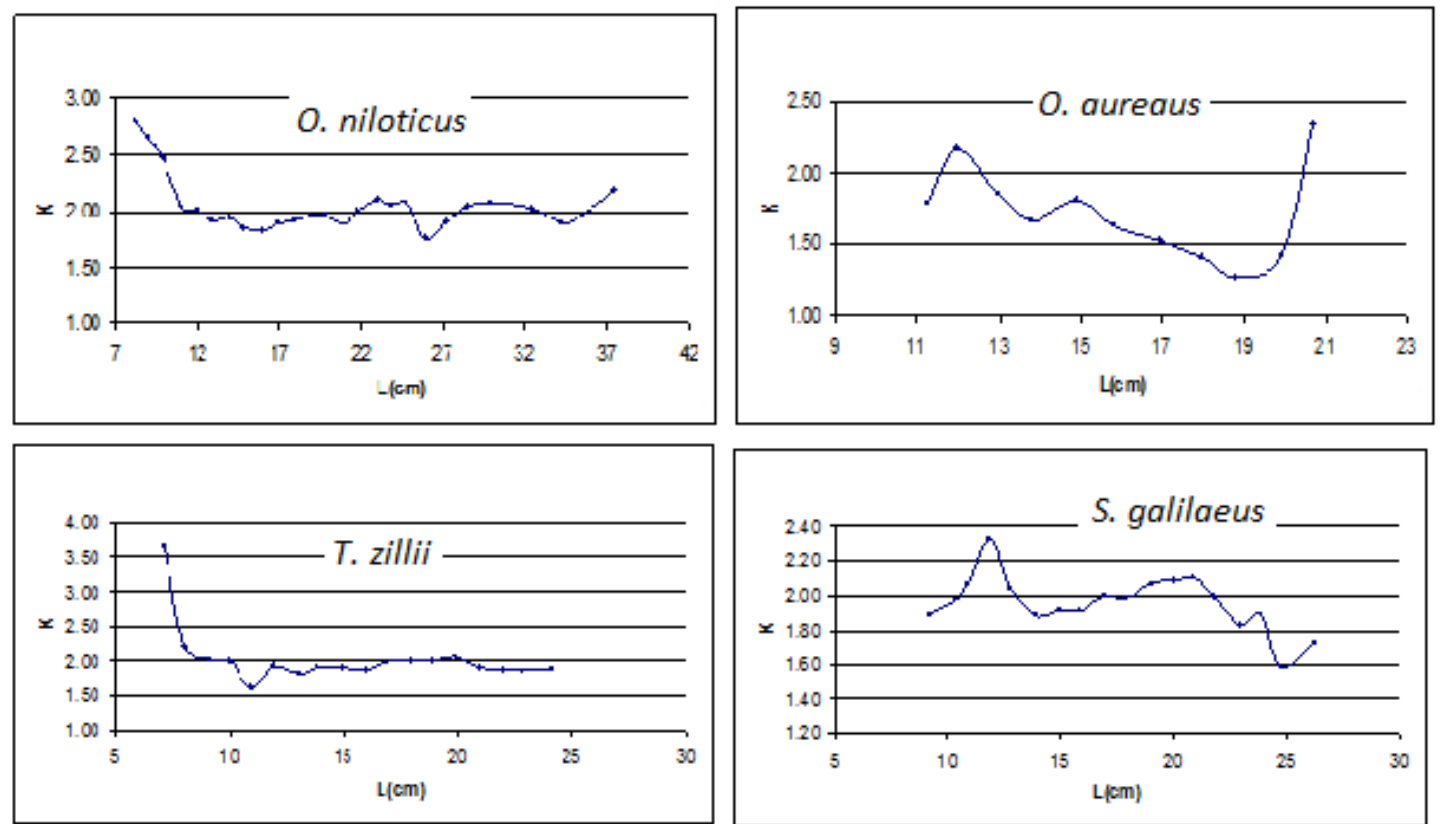

Fig.3. Variation of mean condition factor (K) according to fish size (L) of O. niloticus, O. aureus, T. zillii and S. galilaeus in The River Nile during the period of study.

\section{DISCUSSION}

About 21 species along the River have been detected in the present study. We should mention here the disappearance of some species (as Mugil cephalus, Liza aurata, Anguilla anguilla, Barbus prince, etc...) that were previously recorded by Bishai and Khalil, (1997). Boulenger (1907) recorded 85 species inhabiting the Egyptian Nile waters. Bishai and Khalil (1997) recorded 71 fish species, out of them 22 species were ranked to be common in the commercial catch while 49 were rare and 14 species which were previously recorded by Boulenger (1907) were not recorded during their study, and probably disappeared. El- Sedafy and Kheir (1990) recorded 
that; Egyptian region of the River Nile comprised 31 fish species including only 17 commercial species. The total number of fish species in the Nile drainage Basin including the River Nile, is estimated about more than 800 species. Of these, 128 species belonging to 27 families occur in the River Nile (Witte et al., 2009). Decline of the recorded fish species in the present study than that previously recorded may be due to increase of pollutants in the river.

Length-weight relationships of fishes which are crucial in the fisheries biology and assessments (Garcia et al., 1989; Haimovici and Velasco, 2000), estimate the fish's average weight with a given length category by using the mathematical relation (Beyer, 1987 and Thomas et al., 2003). The present study found that each cichlid species inhabiting the River Nile, Egypt had different length and weight relationship. This may be due to factors such as differences in length and body weight, difference in spawning seasons, differences in food availability, and other environmental conditions. The best average lengths and weights of T. zillii and S. galilaeus observed in the main stream. Based on the result of the current study, T.zillii exhibits isometric growth in both Main stream and Damietta branch (3.0266 and 2.9698, respectively), whereas, S.galilaeus follow the same pattern in Rosetta branch (3.0154).This finding may reflect the higher fertility and the suitable environmental factors (especially feeding behaviors) of both two species. In general, length-weight relationships of the studied four cichlid species in Damietta branch exhibit allometric growth. This may be attributed to increase of pollutants in the river. According to National Water Research Center (2000) and El- Naggar et al. (2009), the River Nile from Aswan to El- Kanater Barrage receives wastewater discharge from 124- point sources, of which 67 are agricultural drains and the remainders are industrial sources.

The coefficient (b) of dependence of length upon weight in the fish of The River Nile in the present study was varying from 2.327 to 3.239 for Lates niloticus and Bagrus bajad respectively. Difference in 'b' values can be due to the combination of various factors such as number of specimens examined, habitat, degree of stomach fullness, gonadal maturity, sex, health and general fish condition, and differences in the observed length ranges of the specimens caught, not all of these were accounted in this study (Abowei et al., 2009 and Wooten, 1998) .

In the present study, the best condition factor of fish of The River Nile was recorded for Haplochromis bloyeti, Sarotherdon galilaeus, Oreochromis niloticus, Tilapia zillii, Hemichromis bimaculatus, Oreochromis aureus and Ctenopharyngodon idella $(2.191,2.006,1.919,1.917,1.843,1.759$ and 1.712, respectively). Meanwhile, the lowest recorded for Mormyrus kannume, Atherina boyeri and Eutroplus (Shilbe) niloticus (0.443, 0.601 and 0.629, respectively). Ragheb (2016) mentioned that the condition factor of Mormyrus kannume in Damietta branch of Nile was 0.76. In addition, the mean condition factor of Atherina boyeri in Lake Iznik, Turky, ranged from 0.41 to 0.80 (Ozeren, 2009), and from 0.49 to 0.60 in Hirfanli Reservoir in Turkey (Gencoglu and Ekmekçi, 2016). Many studies had been conducted to the length-weight relationship and condition factor of tilapia species in the Egyptian waters; in the River Nile (Tharwat, 1995; El-Kasheif, 2003; Mahmoud and Mazrouh, 2008, Authman et al., 2009; Hassan \& El-Kasheif, 2013; El-Bokhty \& El-Far, 2014), in Lake Manzala ( Bayoumi \& Khalil, 1988; Soliman et al., 1998; Shalloof, 1991; Bakhoum and Abdallah, 2002; El-Bokhty, 2006 and Farouk, 2009 ), in Lake Nasser (Latif \& Khallaf, 1987; Agaypi, 1992; Mekkawy et al., 1994; Shenouda et al., 1995 and Khalifa et al., 2000 ), in Abu-Zabal Lakes (Ibrahim et al., 2008 and Shalloof \& El- Far, 2009), in Lake Qarun (Shalloof, 2009), in Wadi El-Rayan depressions (ElGammal and Mehanna, 2003; Mehanna, 2004 and Mehanna, 2005) in Lake Temsah 
(Mahomoud et al., 2011), in Nozha Hydrodrome (Mahmoud et al., 2013) and in Edku Lake (Khalil, 1994 and Abd-Alla \& Talaat, 2000) and in El-Bahr El-Faroany (ElKasheif et al., 2015). Table (7) shows different results from the previous studies, moreover, these differences in results may be due to feeding intensity, climate, gonad maturation and other factors.

Table (7): Comparison of length $(\mathrm{cm})$-weight $(\mathrm{g})$ relationships regression parameters $(\mathrm{a}$ and $\mathrm{b})$ and the condition factor $(\mathrm{K})$ of tilapia species from different locations in Egypt.

\begin{tabular}{|c|c|c|c|c|c|}
\hline Author & Location & Species & $a$ & $b$ & $\mathbf{K}$ \\
\hline Present study & Nile River & $\begin{array}{l}\text { O. niloticus } \\
\text { T. zillii } \\
\text { O. aureus } \\
\text { S. galilaeus }\end{array}$ & $\begin{array}{l}0.018 \\
0.019 \\
0.081 \\
0.024\end{array}$ & $\begin{array}{l}3.017 \\
2.997 \\
2.420 \\
2.926\end{array}$ & $\begin{array}{l}1.92 \\
1.76 \\
1.92 \\
2.01\end{array}$ \\
\hline $\begin{array}{l}\text { Abd-Alla and } \\
\text { Talaat (2000) }\end{array}$ & Lake Edku & O. niloticus & 0.017 & 3.033 & ---- \\
\hline $\begin{array}{c}\text { Bakhom and } \\
\text { Abdallah (2002) }\end{array}$ & Lake Manzalah & $\begin{array}{l}\text { O. niloticus } \\
\text { O. aureus } \\
\text { S. galilaeus } \\
\text { T. zillii }\end{array}$ & $\begin{array}{l}0.043 \\
0.021 \\
0.032 \\
0.055\end{array}$ & $\begin{array}{l}2.851 \\
2.927 \\
2.803 \\
3.035\end{array}$ & $\begin{array}{l}1.47 \\
1.61 \\
1.66 \\
1.46\end{array}$ \\
\hline Mehanna (2004) & Wadi El- Raiyan & $\begin{array}{l}\text { T. zillii } \\
\text { O. aureus }\end{array}$ & $\begin{array}{l}0.016 \\
0.012\end{array}$ & $\begin{array}{l}3.088 \\
3.109\end{array}$ & $\begin{array}{l}---- \\
----\end{array}$ \\
\hline El-Bokhty (2006) & Manzalla & O. niloticus & 0.018 & 3.010 & ---- \\
\hline $\begin{array}{c}\text { Mahmoud \& } \\
\text { Mazrouh (2008) }\end{array}$ & Rosetta Branch & $\begin{array}{l}\text { O. niloticus } \\
\text { T. zillii } \\
\text { O. aureus } \\
\text { S. galilaeus }\end{array}$ & $\begin{array}{l}0.018 \\
0.017 \\
0.025 \\
0.028\end{array}$ & $\begin{array}{l}3.008 \\
3.052 \\
2.872 \\
2.879\end{array}$ & $\begin{array}{l}1.84 \\
1.84 \\
1.79 \\
2.06\end{array}$ \\
\hline $\begin{array}{l}\text { Ibrahim et al., } \\
\qquad(2008)\end{array}$ & $\begin{array}{l}\text { Abu- Zabal } \\
\text { Lakes }\end{array}$ & $\begin{array}{l}\text { O. niloticus } \\
\text { T. zillii } \\
\text { O. aureus } \\
\text { S. galilaeus }\end{array}$ & $\begin{array}{l}0.028 \\
0.023 \\
0.044 \\
0.132 \\
\end{array}$ & $\begin{array}{l}2.859 \\
2.923 \\
2.670 \\
2.226 \\
\end{array}$ & $\begin{array}{l}1.86 \\
1.94 \\
1.89 \\
1.74\end{array}$ \\
\hline $\begin{array}{l}\text { Authman et al., } \\
\text { (2009) }\end{array}$ & $\begin{array}{l}\text { Damietta } \\
\text { Branch }\end{array}$ & $\begin{array}{l}\text { O. niloticus } \\
\text { T. zillii } \\
\text { S. galilaeus }\end{array}$ & $\begin{array}{l}0.028 \\
0.017 \\
0.038\end{array}$ & $\begin{array}{l}3.075 \\
2.779 \\
2.901\end{array}$ & $\begin{array}{l}---- \\
---- \\
----\end{array}$ \\
\hline Shalloof (2009) & Lake Qarun & T. zillii & 0.042 & 2.690 & 2.01 \\
\hline $\begin{array}{l}\text { Shalloof \& El-Far } \\
\qquad(2009)\end{array}$ & $\begin{array}{l}\text { Abu- Zabal } \\
\text { Lakes }\end{array}$ & $\begin{array}{l}\text { O. niloticus } \\
\text { T. zillii } \\
\text { O. aureus } \\
\text { S. galilaeus }\end{array}$ & $\begin{array}{l}0.089 \\
0.019 \\
0.179 \\
0.034\end{array}$ & $\begin{array}{l}2-403 \\
3.147 \\
2.108 \\
2.759\end{array}$ & $\begin{array}{l}1.71 \\
2.30 \\
1.66 \\
1.84\end{array}$ \\
\hline $\begin{array}{l}\text { Mahmoud et al., } \\
\text { (2013) }\end{array}$ & $\begin{array}{c}\text { Nozha } \\
\text { Hydrodrome }\end{array}$ & $\begin{array}{l}\text { O. niloticus } \\
\text { T. zillii } \\
\text { O. aureus } \\
\text { S. galilaeus }\end{array}$ & $\begin{array}{l}0.027 \\
0.029 \\
0.022 \\
0.029\end{array}$ & $\begin{array}{l}2.909 \\
2.885 \\
2.973 \\
2.895\end{array}$ & $\begin{array}{l}2.05 \\
2.07 \\
1.96 \\
2.16\end{array}$ \\
\hline $\begin{array}{l}\text { Hassan and El- } \\
\text { Kasheif (2013) }\end{array}$ & Nile River & O. niloticus & 0.038 & 2.792 & 1.35 \\
\hline $\begin{array}{c}\text { El-Kasheif et al., } \\
(2015)\end{array}$ & $\begin{array}{l}\text { El-Bahr El- } \\
\text { Foraony }\end{array}$ & O. niloticus & 0.037 & 2.801 & 2.13 \\
\hline
\end{tabular}

In the present study, seasonal variation in condition factor $(\mathrm{K})$ was noticed. The best condition of $O$. niloticus recorded in winter in both Rosetta and Damietta branches (2.4 and 2.16, respectively); whereas the lowest recorded in spring in Damietta branch (1.47). This may be attributed to the load on fish during spawning or the feeding intensity in this season. The lowest $(\mathrm{K})$ of $O$. aureus was recorded in spring season in the main stream and Damietta branches (1.5 and 1.44, respectively).This may be correlated to the spawning season of this species in this period. Bolognini et al., (2013) recorded that $\mathrm{K}$ followed the reproductive cycle of most of species, decreasing during the spawning season, and increasing after it. 
Regarding to the mean condition $(\mathrm{K})$ - total size relation of different cichlid, the value of condition factor of $O$. niloticus $O$. aureus, $T$. zillii and $S$. galilaeus inversely related to the size of fish. Anene (2005) reported that, there is a variation in condition factor by size (length) classes in four species of cichlids studied. Shalloof and El- Far (2009) noted that, the values of $(\mathrm{K})$ were inversely related to the size of $O$. niloticus and $O$. aureus and tends to be fairly constant in $T$. zillii and $S$. galilaeus in Abu- Zabal Lakes, Egypt.

\section{CONCLUSION}

In this study, each species of cichlid inhabiting the River Nile, Egypt had different length and weight relationship due to factors such as differences in length and body weight, differences in food availability and other environmental conditions. Tilapia species in the River Nile had positive allometric growth .This may be attributed to increase of pollutants in the river. Therefore, the protection of the River Nile water from pollution achieved better through control of pollution sources. Treatment of sewage water and others pollutant drains before entrance the River Nile is important to protect fish and human from the deleterious effects of pollution.

\section{ACKNOWLEDGMENT}

This manuscript had prepared from some data in a project that titled "The work integrated scientific system to protect areas along the River Nile to reduce the risk of pollutants and increase fish stocks" that sponsored by NIOF. Deep thanks to all staff of this project.

\section{REFRENCES}

Abd-Alla, A. and Talaat, K. M. (2000). Growth and dynamics of Tilapias in Edku Lake, Egypt. Bull. Nat. Inst. Oceanogr. \& Fish., A.R. Egypt, 26:183-196.

Abowei, J. F. N.; Daviesand, O. A. and Eli, A. A. (2009). Study of the length weight relationship and condition factor of five fish species from Nkoro River, Niger Delta, Nigeria. Curr. Res. J. Bio. Sci. 1(3): 94-98.

Agaypi, M. Z. (1992). Studies on length-weight relationship of Oreochromis niloticus and Sarotherodon galilaeus of the High Dam Lake. Working Report of Fishery Management Center, Aswan, Egypt, 1: 11- 24.

Anene, A. (2005). Condition factor of four cichlid species of a man-made lake in Imo state, Southeastern Nigeria. Tur. J. Fish. Aquat. Sci., 5: 43-47.

Authman, M. M.; El-Kasheif, M. A. and Shalloof, K. A. (2009). Evaluation and management of the fisheries of Tilapia species in Damietta Branch of the River Nile, Egypt. World J. Fish. Mar. Sci., 1(3): 167-184.

Bakhoum Sh. A. and Abdallah, M. (2002). Study to detect impacts of pollution on fishery biology of tilapias in Lake Manzalah, Egypt. J. KAU: Mar. Sci., 13: 147-160.

Bayoumi, A. R. and Khalil, M.T. (1988). Tilapia fisheries in Lake Manzala. Egypt. Bull. Nat. Inst. Oceanogr. \& Fish., A. R. E., 14(3): 87-99.

Beyer, J. E. (1987). On length-weight relationships. Part 1: Computing the mean weight of the fish of a given length class. Fishbyte, 5: 11-13.

Binohlan, C. and Pauly, D. (1998). The length-weight table. In: Fishbase 1998: concepts, design and data sources. R. Froese and D. Pauly (Eds). ICLARM, Manila, Philip., pp. 121-123. 
Bishai, H. M. and Khalil, M. T. (1997). Fresh water fishes of Egypt. Department of Nature Protection, Publication of National Biodiversity Unit, No. 9, Egyptian Environmental Affairs Agency (EEAA), Egypt, 229 pp.

Bolognini, L.; Domenichetti, F. G.; Polidori, P.; Searcella, G. and Fabi, G. (2013). Weight- length relationships for 20 fish species in the Adriatic Sea. Tur. J. Fish. Aquat. Sci.,13: 555-560.

Boulenger, G. A. (1907). Zoology of Egypt: The fishes of the Nile (London: hugh Rees Ltd), 578pp.

Chien-Chung, H. (1999). The length-weight relationship of Albacore, Thunnus alalunga from the Indian Ocean. Fish. Res., 14: 87- 90.

Ecoutin, J. M.; Albaret, J. J. and Trape, S. (2005). Length-weight relationships for fish populations of a relatively undisturbed tropical estuary: The Gambia. Fish. Res., 72: 347-351.

El-Bokhty, E. E. (2006). Assessment of family Cichlidae inhabiting Lake Manzala, Egypt. Egypt. J. Aquat. Biol. \& Fish., 10(4): 85-106.

El-Bokhty, E. E. and El-Far, A. M. (2014). Some fishery aspects of Nile tilapia, Oreochromis niloticus at Rosetta branch of the Nile River, Egypt. Egypt. J. Aquat. Biol. \& Fish., 18(3): 41- 51.

El-Gammal, F. I. and Mehanna S. F. (2003). Fisheries management of Sarotherodon galilaeus (Cichlidae) at Wadi El-Raiyan lakes. Bull.Nat. Inst. Oceanogr. Fish., ARE. 29: 51-69.

El-Kasheif, M. A. (2003). Ecological, biological and fisheries studies on some fresh water fishes in the River Nile. Ph. D. Thesis, Mar. Sci. Dept., Fac. Sci., Suez Canal Univ., Ismailia, Egypt, 476pp.

El-Kasheif, M. A.; Authman, M. M. ; Al-Ghamdi, F. A.; Ibrahim, S. A. and ElFar, A. M. (2015). Biological aspects and fisheries management of tilapia fish Oreochromis niloticus (Linnaeus, 1758) in El-Bahr El-Faraouny. Canal, AlMinufiya Province, Egypt. J. Fish. Aquat. Sci., 10(6):405-444.

El- Naggar, A.M.; Mahmoud, S. A. and Tayel, S. I. (2009). Bioaccumulation of some heavy metals and histopathological alternations in liver of Oreochromis niloticus in relation to water quality at different localities along the River Nile, Egypt. World J. Fish. Mar. Sci., 1 (2): 115-120.

El- Sedafy, H. M. and Kheir, M. T. (1990). Fisheries of the Nile in the Egyptian region. Food and Agri. Org. U. N., CIFA 190/symp/, Alex. Univ.

Farouk, A., (2009). Some studies on water pollution of Manzala Lake by heavy metals and others and effect of these on stock assessment of fish. MSc. Thesis, Faculty of Science, Al-Azhar Univ

FishBase (2016). Froese, R. and Pauly, D. (FishBase), World Wide Web electronic publication. www.fishbase.org.

GAFARD, (2015). General Authority for Fish Resources Development. Annual fishery statistics book, Cairo, Egypt.

Gallardo-Cabello, M. E.; Espino-Barr, E.; Garcia-Boa, E. G.; Cabral- Solis, E. G. and Puente- Gomez, M. (2007). Study of the growth of the green jack Caranx caballus Gunther 1868, in the Coast of Colima, Mexico. J. Fish. Aquat. Sci., 2: 130- 139.

Garcia, C.B.; Buarte, J.O.; Sandoval, N.; Von Schiller, D. and Najavas, P. (1989). Length-weight relationships of demersal Fish from the Gulf of Salamanca, Colombia. Fishbyte, 21: 30-32. 
Gencoglu, L. and Ekmekçi, F. G. (2016). Growth and reproduction of a marine fish, Atherina boyeri (Risso 1810), in a freshwater ecosystem. Turk. J. Zool. 40(4):1-9.

Haimovici, M. and Velasco, G. (2000). Length weight relationships of marine fishes from souther Brazil. The ICLARM Quartely, 23(1): 14-16.

Hassan,A. A. and El-Kasheif, M. A. (2013). Age, growth and mortality of the cichlid fish Oreochromis niloticus (L.) from the River Nile at Beni Suef Governorate, Egypt. Egypt. J. Aquat. Biol. \& Fish., 17(4): 1-12.

Ibrahim, S. M.; Shalloof, K. A. and Salama, H. M. (2008). Effect of environmental conditions of Abu-Zabal Lake on some biological, histological and quality aspects of fish. Global Veterinaria, 2(5): 257-270.

Khalifa, U. S. ; Agaypi, M. Z. and Adam, H. A. (2000). Population dynamics of Oreochromis niloticus L and Sarotherodon galilaeus. In: "Sustainable Fish Production in Lake Nasser: Ecological Basis and Management Policy". J. F. Craig (ed.). ICLARM Conf. Proc., 61: 184p.

Koutrakis, E.T. and Tsikliras, A. C. (2003). Length-weight relationships of fishes from three northern Aegean estuarine systems (Greece). J. Appl. Ichthyol., 19:258-260.

Latif, A. F. and Khallaf, E. A. (1987). Growth and mortality of Tilapia species in Lake Nasser. Sci. J. Fac. Sci., Menoufia Univ., 1(1): 34-53.

Lawson, E. O., (2011). Length-weight relationship and fecundity estimates in mudskipper, Periophthalmus papilio (Bloch and Schneider, 1801) caught from the mangrove swamps of Lagos Lagoon, Nigeria.J. Fish. Sci., 6: 264- 271.

Le Cren, E. D. (1936). The length-weight relationship and seasonal cycle in gonad weight and condition in the perch (Perca fluviatilis). J. Anim. Ecol., 20(2):201-219.

Mahmoud, H. H. \& Mazrouh, M. M. (2008). Biology and fisheries management of Tilapia species in Rosetta branch of the Nile River, Egypt. Egyp. J. Aquat. Res., 34: 272- 284.

Mahmoud,W. F.; Amin, A. M.; Elboray, K. F.; Ramadan, A. M. and ELHalfawy, M. M. (2011). Reproductive biology and some observation on the age, growth, and management of Tilapia zilli (Gerv, 1848) from Lake Timsah, Egypt . Int. J. Fish. \& Aqua., 3(2): 16-26.

Mahmoud, H. H.; Ezzat, A. A.; El-Sayed, A. T. and El Samman, A. (2013). Fisheries management of cichlid fishes in Nozha Hydrodrome, Alexandria, Egypt. Egypt. J. Aquat. Res., 39(4): 283-289.

Mehanna, S. F. (2004). Population dynamics of two cichlid,Oreochromis aureus and Tilapia zillii from Wadi El- Raiyan lakes, Egypt. Agri. \& Mar.Sci., 9(1): 9- 16.

Mehanna, S. F. (2005). Population dynamics and management of the Nile tilapia Oreochromis niloticus at Wadi El-Raiyan Lakes, Egypt. Afr. J. Biol. Sci., 1: 79-88.

Mekkawy, I. A.; Mohamad, S. H.; Abass, F. F. and Okasha, S. A. (1994). Some biological aspects of Oreochromis niloticus (Linnaeus, 1758) from Lake Nasser, Egypt and the effect of Lake Impoundment. Bull. Fac. Sci., Assiut Univ., 23(2E): $101-142$.

Moussa, S. (2003). Impact of inorganic pollutants on aquatic environment and fish performance in Lake Borollus. Ph. D., Inst. Env. Stud. \& Res., Ain Shams University, $210 \mathrm{pp}$. 
National Water Research Center (NWRC) WL/ DELFT Hydraulics (2000). National water Resources Plan for Egypt, water Quality, and pollution control Technical report No. 5.

Oni, S.K., Olayemi, J. Y. and Adegboye, J. D. (1983). Comparative physiology of three ecologically distinct fresh water fishes, Alestes nurse Ruppell, Synodontis schall Bloch and S. schneider and Tilapia zill Gervais. J. Fish Biol., 22: 105109.

Ozeren, S. C. (2009). Age, Growth and Reproductive Biology of the Sand Smelt Atherina boyeri, Risso 1810 (Pisces: Atherinidae) in Lake Iznik, Turkey. J. Fish. Inter., 4(2): 34-39.

Ragheb, E. (2016). Growth pattern and natural mortality of elephant fishes (Mormyrus kannume, Mormyridae) in the Damietta branch of Nile, Egypt. Egyp. J. Aqua. Res. 42(2): 161- 168.

Raslan, Y. and Abdelbary, M. R. (2001). Economical and environmental aspects of navigation development in the Nile. Sixth International Water Technology Conference, IWTC 2001, Alexandria, Egypt, 10 p.

Reynold, T. D. (1968). The biology of the clupeids in the New Volta. In: Man-made Lakes. The Accra Symposium. Ghana University Press, Accra.

Ricker, W. E. (1975). Handbook of computations and interpretations of biological statistics of fish production. Bull. Fish. Res. Board Canada 191: 382 p.

Sedaghat, S. and Hoseini, S. A. (2012). Length- weight and Length- Length relationships of Cyprinion macrostomomus, (Heckel, 1843) in Dalaki River Bushehr, in South of Iran. World J. Fish. Mar. Sci., 4(5):536- 538.

Shalloof, K. A. (1991). Biological studies on Tilapia species in the middle region of Manzalah Lake. M. Sc. Thesis, Zool. Dept., Fac. Sci., El-Mansoura Univ., 244pp.

Shalloof, K. A. (2009). Some observations on fisheries biology of Tilapia zillii (Gervais, 1848) and Solea vulgaris (Quensel, 1806) in Lake Qarun, Egypt. World J. Fish Mar. Sci., 1(1): 20-28.

Shalloof, K. A. and El- Far, A. M. (2009). Age, growth and fishery biology of cichlid spp. In Abu-Zaable lakes, Egypt. J. Aquat. Biol. Fish., 13:101- 116.

Soliman, I. A.; Shawky, K. A. and El-Agamy, A. E. (1998). Some biological aspects of four cichlid species in Lake Manzalah. Bull. Nat. Inst. Oceanogr. Fish., A.R.E, 24: 313-323.

Tharwat, A. A. (1995): Biological and ecological studies on fishery resources of the River Nile. Ph. D. Thesis, Fac. Agricult., Cairo Univ., 215pp.

Thomas, J.; Venu, S. and Kurup, B. M. (2003). Length- weight relationship of some deep-sea fish inhabiting the continental slope beyond $250 \mathrm{~m}$ depth along the West Coast of India. NAGA, WorldFish Center Quaterly, 26(2): 17-21.

Witte, F.; Martien J.; van Oijen, P. and Sibbing, F. A. (2009). Fish fauna of the Nile. In: The Nile: Origin, Environments, Limnology and Human Use. H. J. Dumont(ed.), Monographiae biologicae, 89: 647- 677.

Wooten, R. J. (1998). Ecology of teleost fishes. Kluwer Academic Publishers, Dordrecht, the Netherlands. 


\section{ARABIC SUMMARY}

علاقة الطول والوزن ومعامل الحالة لبعض أسماك نهر النيل في مصر بالإشارة لأربع أنواع من أسماك البلطي

$$
\begin{aligned}
& \text { كريمان أحمد شوقي شلوف ',"و علاء محمود الفار' }
\end{aligned}
$$

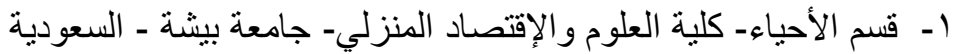

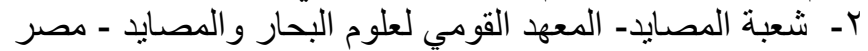

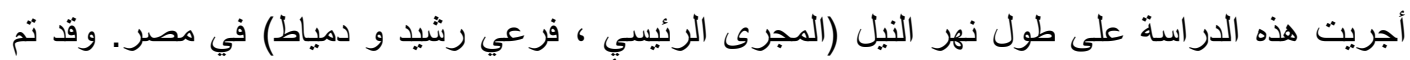

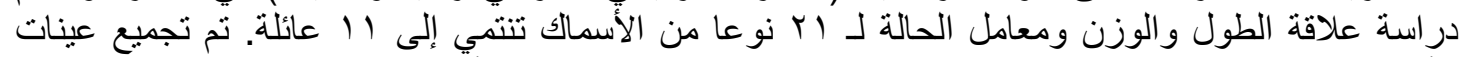

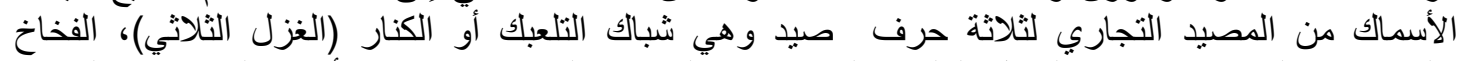

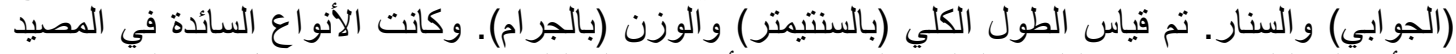

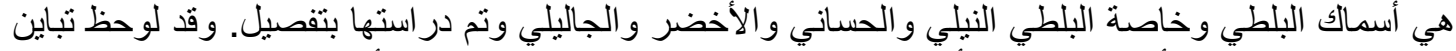

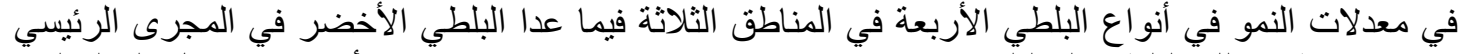

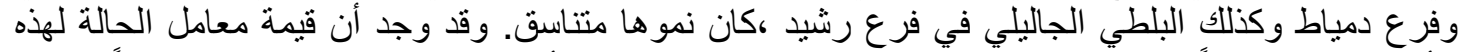

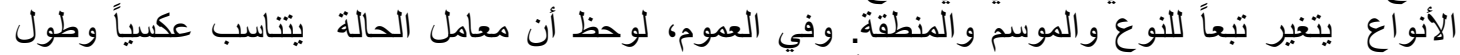

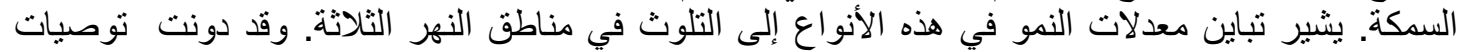

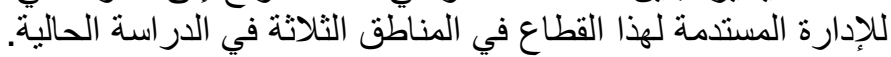

